\title{
The Map of the Heavens at the Chateau de Saint-Jean-de-Chepy
}

\author{
Joël Barbier \\ AEROSPATIALE, Sciences et Archéologie, \\ 100 Bd. du Midi, B.P. 99, F-06322 Cannes-La Boca, France
}

\begin{abstract}
In the Dauphiné, near Tullins, there is a fortified manor-house known as the Chateau de Saint-Jean-de-Chépy, built in the 13th century, that has in one of its towers an Italian Renaissance map of the heavens painted on the ceiling. The south tower could have been designed for astronomy, with the octagonal-roofed, second floor with its seven windows being used for observation. The first and ground floors have hemispherical vaults, and painted on the ceiling of the first floor there is a map of the heavens that is unique in France. It is painted on the ceiling, with the southern constellations extending down onto the cylindrical wall. It is similar to Italian Renaissance maps, like those in the Old Sacristy at San Lorenzo in Florence (painted by Brunelleschi in 1429), in the Villa Farnesine at Rome (Peruzzi, 1511), and in the Villa Farnese at Caprarola (artist unknown, 1575).

An owner of Saint-Jean-de-Chépy was Maurice Bressieu (1546-1617), a distinguished mathematician, holding the mathematical chair at the Collège de France between 1575 and 1586. He wrote Metrices Astronomicae, which was "highly regarded by mathematicians" and became Speaker for the Kings of France at the Vatican. Pope Sixtus-Quintus made him steward of the Vatican Library. It therefore seems very likely that the map could have been painted for him.
\end{abstract}

